\title{
The Multifaith Campus: Transforming Colleges and Universities for Spiritual Engagement
}

\section{I}

NSTITUTIONS OF HIGHER EDUCA-

TION in this country were founded nearly four centuries ago with the recognition that the connection between mind and spirit was fundamental to education. As articulated by Cardinal Newman in the nineteenth century and Victor Kazanjian in the twenty-first, early educators saw education as a process of developing the whole person (mind, spirit, and body) for civic leadership. As explained by these writers, as well as George Kuh, Jill Shedd, and Elizabeth Whitt, scholars who valued the processes of inquiry and discovery began over time to feel constrained by Christian religious dogma and responded by rejecting anything other than intellectual engagement in the academy. In both stateassisted and independent colleges and universities, this shift resulted in the marginalization of the emotional, social, and spiritual aspects of the lives of all members of the campus community (faculty, staff, and students).
Concurrently, the nation's political birth began with the ardent belief that this would be a country where the state would neither dictate religious commitment nor seek to restrain the expression of it. Kazanjian, as well as Carney Strange and Judy Rogers, acknowledges that these two developments contributed to the existing apprehension and resistance to engaging questions of spirituality and religion in the academy.

The marginalization of explicit spiritual engagement in the academy happened at a time when the religious identities of faculty, staff, and students in US colleges and universities were nearly homogeneously Protestant Christian due mainly to exclusionary admissions practices. Using Wellesley College, founded as a nondenominational college, as an example, Kazanjian notes that even institutions founded to be nonsectarian have been influenced by Protestant Christian norms and values. As he explains, institutional structures carry and communicate norms of religious privilege rooted in a Protestant Christian past. Examples on campuses

Published online in Wiley Online Library (wileyonlinelibrary.com) (c) 2011 by American College Personnel Association and Wiley Periodicals, Inc. DOI: 10.1002/abc.20049 


\section{The question for the twenty-first century must not be how to accommodate that religious diversity in the academy. We agree with Kazanjian's assertion that the question must be instead, "How [do] religion and spirituality enhance the education of our students?"}

include physical structures like campus chapels that employ Protestant Christian architecture and iconography, as well as rituals, such as convocation, baccalaureate, and commencement exercises that appropriate Protestant Christian liturgical forms.

Today's campuses are no longer characterized by religious homogeneity. Multiple beliefs and faith commitments are held by students, faculty, and staff across the campus commons. The question for the twenty-first century must not be how to accommodate that religious diversity in the academy. We agree with Kazanjian's assertion that the question must be instead, "How [do] religion and spirituality enhance the education of our students?" (p. 4). Approaching the topic in this way allows us to engage in the creative and innovative processes required for campus transformation from what Diana Eck calls religious exclusivity to religious pluralism. Engaging religious pluralism and interfaith cooperation in this way encourages a renewed commitment to a holistic educational paradigm that regards mind, body, and spirit as cooperative and mutually enhancing aspects of the human experience. This principle is fundamental to student affairs practice and dates back to the American Council on

Dafina Lazarus Stewart is an associate professor of higher education and student affairs at Bowling Green State University.

Michael M. Kocet is an associate professor of counselor education and student affairs program director at Bridgewater State University.

Sharon Lobdell is a student advisor in the Student Success Center at the University of Michigan-Dearborn.

We are grateful to the Rabbi Joshua Fiegelson at Northwestern University for his contributions to the initial ideas that informed this piece.

We love feedback. Send letters to executive editor Jean M. Henscheid (aboutcampus@uidaho.edu), and please copy her on notes to authors.
Education's 1937 landmark publication, Student Personnel Point of View.

\section{Enhancing the Campus Climate for Religious Pluralism}

$\mathbf{R}$ ELIGIOUS PLURALISM IS NOT THE FIRST TYPE OF DIVERSITY higher education has faced. In a 1998 article, Sylvia Hurtado, Jeffrey Milem, Alma Clayton-Pedersen, and Walter Allen advocated the necessity of using a multidimensional framework for enhancing the campus climate for racial and ethnic diversity. Their model began with acknowledging the institutional legacy for racial inclusion and exclusion. Next, structural diversity, as evidenced by the proportional representation of diverse racial groups, was considered as a product and reflection of the institution's legacy. Assessing the climate for racial diversity followed, with the recognition that visibility of racial diversity, or lack thereof, and institutional legacies affect how a campus climate is perceived by those who are members of racially marginalized groups. These scholars also contended that those in the majority, whose worldviews and cultural values are reflected in the institution's structures and consequently insulated by privilege, often do not perceive the campus climate in the same way as members of marginalized groups. The last dimension of the model examined relationships among and between different groups on campus. Increased intergroup conflict is likely to accompany an increase in the representation of diverse voices and experiences. However, as Parker Palmer asserts, conflict is not something to escape, but rather should be embraced as the only means of developing meaningful and substantive communities that sustain diversity.

We believe that a similar approach is warranted and helpful for transforming campus climates for religious and secular diversity because it engages the entirety of the campus environment. We also borrow from Kathleen Manning and Patricia ColemanBoatwright their idea of moving toward multicultural 


\section{Transformation for engaging spirituality and religious and secular pluralism is not a simple matter of recruitment and civility.}

universities as a model for institutional transformation regarding religion, secularism, and spirituality. Transformation for engaging spirituality and religious and secular pluralism is not a simple matter of recruitment and civility. Such transformation requires faculty, staff, and students to invest in the long-term work of examining and revising institutional structures to dismantle privilege, while contemplating what it means to live life together as a campus community, mobilizing our beliefs about meaning and purpose to enhance the educational journey. Throughout this essay, we use Hurtado and her colleagues' framework to illustrate the levels of transformation from nonsectarian to multifaith colleges and universities. We also draw on Sharon Parks's model of faith development regarding forms of community to help illustrate the nature of community at each level of transformation.

\section{From Exclusivity to Cooperation}

$\mathrm{W}^{\mathrm{s}}$ E SEE THE TRANSFORMATION OF CAMPUSES toward multifaith communities as a journey of increasing complexity in institutional approaches and commitments. We believe this journey to be most important for nonsectarian institutions given the greater religious, spiritual, and secular diversity likely to exist on campus. However, sectarian colleges, particularly those that open admission and employment to students, faculty, and staff of diverse religious traditions and beliefs, can also seek to resist religious hegemony without inherently undermining the institution's guiding religious traditions.

We envision institutions as located at one of four different points. We use the terms apathy, awareness, acceptance, and active engagement as place markers for this journey. At times, the whole institution may be situated in one place, while at others, separate units or elements of the campus environment may be at different locations. Each location reflects a different worldview toward religious and secular diversity in higher education and institutional practices concerning it. Our descriptions of these locations are informed by multiple sources, including scholarly writings, but are more so meant to reflect the lived experiences of our colleagues and students whose stories have been shared in multiple settings over the last several years.

\begin{abstract}
Apathy
A religiously apathetic campus is one where dialogue about the role of religion, secularism, and spirituality in enhancing education for students is muted. The institutional legacy reflects a mono-religious heritage that is unexamined, despite the institution's possibly nonsectarian posture. On sectarian campuses, the institution's religious heritage regarding the motivation and circumstances for its founding are not discussed or widely known or understood. Regardless of the institution's sectarian character, Christian religious privilege is unrecognized and unchallenged. Members of religious minority groups are few in number and those that are on campus may characterize the campus climate as hostile and unwelcoming. For these students, faculty, and staff, their differences in religious, spiritual, or secular belief and practices are perceived to be a threat to the traditional values of the institution's founding. Members of religious majority groups rarely consider the religious and spiritual aspects of their identities and why they hold the beliefs that they do. Friendships across lines of religious, spiritual, and secular identities are rare. For support and community, members of religious minority groups form alliances rooted in the need to oppose religious hegemony on campus. Similar to Sharon Parks's forms of community in her model of faith development, such campuses are conventional, closed to others, and defined by homogeneity.

Campus attendance policies can illustrate such apathy by not even acknowledging that the traditional institutional calendar may create conflicts for students, faculty, and staff whose religious and spiritual observances are not reflected in the timing of classes or holiday breaks. Apathetic campuses might espouse that they want to include all members of the community but fail to acknowledge that differences even exist in pathways to meaning, purpose, and belief.
\end{abstract}

\footnotetext{
Awareness

Religiously aware campuses acknowledge that religious and secular diversity exists in their campus community. The institution's history as monoreligious may also be discussed or at least included in the story of its founding. Ecumenism within a Christian framework may be celebrated, but other expressions of faith and belief are included only to the extent that they can be co-opted
} 
to support Christian religious privilege. The awareness of difference is enacted by an attitude and atmosphere of tolerance as an end goal. As Kazanjian describes, tolerance is "little more than conflict arrested" (p. 6). Although tolerance may effectively squelch incivility, Kazanjian notes that it sets up "a glass wall where protected people can see one another going about parallel lives" (p. 6). Tolerance functions as an impediment to deep and substantive engagement about differences and cannot lead to a pluralistic community.

Similar to Kathleen Manning's characterization of color-blindness as a philosophical approach to difference, awareness and tolerance do not see a role for religion, spirituality, and secularism in enhancing the educational experience for students, staff, and faculty. Instead, religious and existential identities are unexamined and treated as tangential to the educational experience. Campuses characterized by awareness and tolerance use an additive approach to the representation of religious and secular diversity in staffing, programming, and services. The spiritual practices and needs of religious minority groups are accommodated when specific requests are made, while institutionalized structures that systematically confer religious privilege go unrecognized and unquestioned. Using Sharon Parks's model, inter- and intragroup relations at these colleges may be characterized by diffuse communities where any relationship is as good as any other because differences are seen as irrelevant and not useful in determining how to best communicate and engage across lines of difference.

Many colleges and universities today acknowledge the rich diverse and multicultural tapestry that characterizes their campus. Whereas a campus might have been solely Christian or Judeo-Christian, there are now a multitude of other religious and secular perspectives that have to be considered. Each of these groups has its own sacred calendar, and the result is that the classroom experience can be greatly affected. Most campuses have policies that allow for a student's absence from class due to the observance of a religious holiday. Some have forms that the students must submit to the instructor(s) in advance of the absence. Still others will allow an absence if approved by the faculty member. Although allowing students to miss class accommodates their religious or spiritual practices, it does not address this part of the student's identity and how it shapes them. The connection of meaning, experience, and involvement to the learning process is not examined.

An argument could be made that these attendance policies only address the teaching component of the educational process. Arthur Chickering advocates that competence in interpersonal relationships, including engaging differences across social identities, and problem resolution are necessary to help students prepare for a productive career. Our campuses need to look more at how students learn; excusing a student's absence does not resolve the remaining issue that the student is excluded from the learning that continues without their input or derived benefit.

On the other side of the teaching and learning relationship, Alexander Astin notes that many faculty and staff are on a search for meaning and trying to discover ways to make their lives and their institutions more whole. Faculty and staff that need to be absent due to religious observances can also be accommodated, but as with students, it is little more than receiving permission to miss the time from work. Faculty members are expected to announce such absences on their syllabi and to ensure that their courses are covered. As with student excused absences, bureaucratic processes to accommodate faculty and staff absences continue to reinforce religious hegemony by marking those whose beliefs are not part of the dominant majority as exotic and/or disruptive. Christian faculty and staff do not have to announce that they will be absent from work to attend services on certain holidays because, more than likely, classes are already canceled and the institution is closed.

It is an advancement to acknowledge the diversity of a campus through creating accommodating policies; however, unless steps are made to go beyond tolerance, transformation that leads to pluralism will not take place. Pluralism requires the participation and inclu-

\section{Apathetic campuses might espouse that they want to include all members of the community but fail to acknowledge that differences even exist in pathways to meaning, purpose, and belief.}


sion of diverse perspectives and worldviews. Therefore, intentionally pursuing pluralism also means having discussions that acknowledge the implications of allowing classes and campus events to continue without the inclusion and participation of all its members. Although it is likely not logistically practical to create a calendar that would equally honor and respect all religious, secular, and spiritual observances, there is a difference between tolerant awareness couched in bureaucracy and pluralistic engagement fostered through intentional dialogue.

\section{Acceptance}

Campuses characterized by religious acceptance recognize the pitfalls created by only promoting tolerance. Such colleges and universities seek to incorporate a wide variety of religious beliefs, not just ones that reinforce Christian assumptions about the nature of reality, deity, and humanity. Accepting campuses are characterized by religious pluralism and seek to dismantle religious privilege across institutional structures. At state-supported and independent nondenominational colleges and universities, the history of ecumenism is used as a rationale for promoting religious pluralism. At sectarian colleges, religious majority students are encouraged to experience other traditions and to allow those experiences to prompt deep reflection about how they have formed their own faith commitments. In line with a realist philosophy of identity advocated by Amie Macdonald and Susan Sánchez-Casal, accepting campuses recognize the epistemic value of religious identity in creating knowledge and informing ways to approach dialogue across differences. These campuses seek to achieve a secular education through the intentional incorporation of multiple perspectives and ways of being, uniting intellect and spirit in the pursuit of a liberal education.

Relationships between students, faculty, and staff of different religious and existential identities are characterized by deep respect, empathy, and serious engagement of the differences in their perspectives and what those differences may reveal about other issues of privilege and identity. As Kazanjian illustrates with Wellesley, specific structures are created that encourage interreligious dialogue, critique of exist- ing systems of privilege, and collective re-visioning of campus traditions and symbols. Members of religious minority groups can function as partners with equal voice in shaping the campus climate, beyond merely combating oppression. Drawing again on Sharon Parks's model, intra- and intergroup relations at religiously accepting campuses may reflect the characteristics of self-selected groups. In these communities, individuals seek affiliations with others that support a meaning-making system characterized by tentative commitments open to re-evaluation and revision.

Here we illustrate a few examples of ways in which campuses can facilitate and promote religious and secular diversity. One example is by providing a "Spirit Week" - a week of programming, classroom, and cocurricular engagement among faculty, staff, and students that fosters greater awareness and knowledge about diverse religious and faith traditions, as well as humanistic philosophies. Speakers from within and outside the institution can share their expertise. Panels can be organized that afford opportunities for examination of religion, faith, spirituality, and secularism from a wide range of viewpoints. For example, a panel consisting of faculty from disciplines such as philosophy, history, political science, biology, and art could address how religion, secularism, and spirituality impact each of their fields. Each panelist could speak to the challenges and complexities of addressing faith development and religious and secular pluralism, as well as how religious diversity can benefit their academic discipline and their field. Similarly, student affairs professionals could convene similar panels during "Spirit Week" in residence halls and student government association meetings or within student organizations. Students from both traditional and unique faith and humanistic traditions could be brought together as a panel to talk about the importance of their belief system, how it helps shape their identities, as well as how their beliefs shape their view of the world. The panel can also involve students who share how spirituality and religion assist them in creating psychological and emotional coping skills during challenging times, and how spirituality and religion shape the manner in which they make meaning in the world.

\section{Campuses characterized by awareness and tolerance use an additive approach to the representation of religious and secular diversity in staffing, programming, and services.}




\section{Our campuses need to look more at how students}

\section{learn; excusing a student's absence does not resolve the remaining issue that the student is excluded from the learning that continues without their input or derived benefit.}

Bluffton University provides one example of how religious acceptance might look at a denominational college. Bluffton is affiliated with the Mennonite Church, a Protestant Christian denomination. In its alumni magazine, it describes itself as an "open circle" institution, defined as "[one] that maintain[s] a strong emphasis on a particular set of religious values and commitments, but [is] intentionally open to people with other religious (or nonreligious) commitments." What makes the open circle model distinct is that institutions that subscribe to its philosophy strive to maintain their religious foundation and mission yet welcome students, faculty, and staff from diverse religious and secular backgrounds and see religious and secular diversity as a benefit that contributes to the growth of all. Bluffton uses the open circle model as a way to connect with social justice issues and seeks to provide students with purposeful opportunities to connect their varied beliefs with ways to tackle global issues like poverty, homelessness, and racism.

There are more specific measures that faculty, as well as student affairs staff, can engage in in order to support religious and secular pluralism. Faculty can be cognizant when crafting course syllabi to ensure that class meetings, assignment due dates, and other course expectations do not conflict with students' religious or spiritual traditions, rituals, feasts, or holy days. Faculty are encouraged to devise classroom policies addressing inequities and allowing students, especially those from underserved or nonprivileged traditions, to miss class in order to meet their spiritual or religious obligations without penalty or having to complete additional academic requirements. Such additional requirements essentially punish students for being spiritually or religiously observant. Faculty should work collaboratively and respectfully with students so that they do not feel marginalized for missing class due to religious or spiritual commitments.

Likewise, we also encourage student affairs professionals to take steps to reduce conflicts for staff (both paraprofessional and professional) with meetings and work duties. In order to affirm spiritual and religious diversity on campus, supervisors should apply (or develop, if necessary) a consistent policy equally to all staff, regardless of their religious, spiritual, faith tradition, or secular philosophies. Students and staff should not experience negative repercussions due to missing class or work obligations because they choose to practice their faith. Faculty and staff must move beyond knowledge of only traditional Christian calendars and keep apprised of other holy days, celebrations, and spiritual events that have meaning to those we serve. Vanessa Bing and Rosemary Talmadge identify specific exercises and techniques that faculty can integrate into key educational moments involving learning and growth about spiritual and religious pluralism. They included examples such as: (a) faculty reflecting on best ways to integrate spirituality and religion into the curriculum; (b) personal exploration of how faculty members' own experiences with religion and spirituality impact classroom climates; and (c) establishing a safe environment for facilitating healthy and open dialogue on religion, secularism, and spirituality, ensuring that students' diverse voices are expressed and encouraged, and that faculty avoid taking certain sides of a religious or spiritual discussion.

Student affairs staff can infuse these strategies into their work with students as well, by being intentional about discussing spirituality, religious, and secular pluralism during staff meetings, programming, crisis intervention services, and everyday encounters with students experiencing spiritual identity development milestones. Lois Calian Trautvetter encourages student affairs professionals and faculty to examine how students' and staff members' religious, secular, and spiritual identities shape students' perceptions, values, belief systems, and interpersonal relationships. Some professionals may choose to not integrate questions of meaning and purpose from a religious and secularist pluralist perspective into curriculum or staff training because they may not feel adequately prepared or 
competent to facilitate dialogue on religious, spiritual, and secular pluralism. Increasing one's knowledge and awareness will positively increase staff and faculty members' capacities to exhibit skills and competencies that are affirming.

\section{Active Engagement}

Campuses that actively engage religious diversity help to promote both religious commitment as well as pluralistic communities. Through active engagement, as Eboo Patel wrote, individuals can uphold common values that unite different faiths and beliefs while learning how those different traditions approach these common values within the context of specific religious sagas and practices. This is made possible by nurturing deep reflection about meaning, purpose, and faith and by creatively engaging conflict around differences in approach to these concepts to develop communities based on commonly held values, not commonly practiced traditions.

Institutions that actively engage religious, spiritual, and secular diversity use the religious and secular pluralism described earlier as a foundation for interfaith cooperation. Interfaith cooperation connects religious pluralism with social justice advocacy to address local, national, and global issues. Patel's Interfaith Youth Core (IFYC) embraces a service-learning methodology to bring together groups of young people of different faiths and beliefs for volunteer work addressing social issues like hunger, homelessness, and poverty to act out their faith while learning about the faiths of others. Such collective action mobilizes young people to use their faith to define what they support, instead of what they reject. Further, such interfaith cooperation reflects a campus that has been transformed as a multifaith college or university whose students are prepared to be civic leaders in an increasingly diverse and complex global community. Parks would likely identify such campus communities as those open to others, having a desire to engage with different beliefs and traditions, creating a "capacity to embrace a more adequate truth" (p. 150).
Community service, as used by IFYC, is an example of campuses promoting active engagement with interfaith cooperation. Many institutions of higher learning have created offices designed to spur student engagement in off-campus organizations designed to serve a constituency in local, national, or even world communities. As Michelle Lelwica points out when addressing religious diversity and its accompanying challenges, dialogue on religious and spiritual pluralism can help students begin to tackle global problems. She further sees institutions working to create meaningful opportunities for students to gain spiritual insights that will embolden them to seek solutions garnered from a spiritual, religious, or secular perspective different from their own. There is inherent value and worth in learning about a different religious or faith tradition and how people view the world through both similar, as well as different, cultural lenses.

\section{Recommendations for Promoting TRANSFORMATION}

$\mathrm{T}$ RANSFORMING ANY INSTITUTION to move through the four different points mentioned earlier (apathy, awareness, acceptance, and active engagement) can present a significant challenge, particularly without institutional leadership and support. Michael Kocet and Dafina Lazarus Stewart have proposed an initial model of competencies to engage spirituality, as well as religious and secular pluralism. Such a model aids in furthering the personal awareness, knowledge, and skills necessary to become more multiculturally and spiritually literate.

We recommend that faculty and student affairs practitioners develop partnerships with outside constituents who focus on religious or spiritual leadership. These partnerships may include, but are not limited to, shamans, imams, priests, ministers, rabbis, healers, scientists, philosophers, teachers, and others who specialize in religion, secularism, or spiritual development. When working with students who are experiencing existential disconnection or crises, faculty and

\section{It is an advancement to acknowledge the diversity of a campus through creating accommodating policies; however, unless steps are made to go beyond tolerance, transformation that leads to pluralism will not take place.}




\section{Members of religious minority groups can function as partners with equal voice in shaping the campus climate, beyond merely combating oppression.}

staff should make strong attempts to reach out to these important and knowledgeable community resources.

Finally, in order for religious, secular, and spiritual pluralism to flourish at our institutions, it is absolutely essential for campuses to have key leaders actively serving as advocates who recognize that religious and secular pluralism falls under the model of multicultural competence. Campus vice presidents, deans of students, directors, and program coordinators alike must place a high value on having critical dialogue on religion, secularism, and spirituality as a necessary part of the intellectual, emotional, moral, and spiritual development of the campus community. We encourage senior student affairs officers, especially at public, nonsectarian institutions, to consider creating offices of spiritual life that establish councils or committees, composed of faculty, staff, and students, whose mission is to promote the existential wellness of its members throughout the institution and to address inequities in treatment, services, or access regardless of the individual or individuals. Such councils or committees could be charged with recommending campus policies, procedures, and services that support best practices in the area of spiritual, religious, and secular pluralism.

\section{Conclusion}

$\mathrm{I}_{\mathrm{I}}^{\mathrm{N}}$ N ORDER FOR HIGHER EDUCATION TO INCORPORATE, not just accommodate, the diverse religious, spiritual, and secular tapestries that cover our campuses, an examination of how these issues affect the learning process must be conducted. As stated in ACPA's and NASPA's Learning Reconsidered, the construction of meaning does not occur only in the academic context. If student learning outcomes seek to satisfy the need for interpersonal and intrapersonal competency, the issue of spirituality, religion, and meaning making must have as its primary outcome the holistic and transformative development of the student. In turn, this will lead to the transformation of the entire campus, for it will truly embrace the rich, culturally diverse makeup of its entire population.

Strange and Rogers state that "we are also drawn to questions of ultimate purpose in our own lives and our desire to share that journey with others ..." (p. 27). They assert that individuals are concerned with ques- tions about what shapes us and how this in turn affects how people relate to their world. Throughout its history, higher education in the United States has shifted from one rooted in religion to one that is charged with educating a diverse population with multiple beliefs, practices, and philosophies. The reality of this diversity neither obscures nor undermines the concurrent reality expressed by Strange and Rogers. Therefore, institutions must reintegrate meaning and purpose into a holistic picture of student development. Yet this reintegration must acknowledge and honor the diverse and multiple ways that faculty, staff, and students follow their paths toward meaning and purpose. Transforming colleges and universities into multifaith institutions is a critical process informing how effectively institutions are able to take that journey with their students.

\section{Notes}

American College Personnel Association \& National Association of Student Personnel Administrators. (2004). Learning reconsidered: A campus-wide focus on the student experience. Washington, DC: Author. Retrieved from http://www.naspa.org

American Council on Education. (1937). The student personnel point of view. Washington, DC: Author. Retrieved from http://www.myacpa.org/pub/documents/1937.pdf

Astin, A. A. (2004). Why spirituality deserves a central place in higher education. Spirituality in Higher Education Newsletter, 1(1), 1-12.

Bing, V., \& Talmadge, R. (2008). Speaking of religion: Facilitating difficult dialogues. Diversity $\mathcal{E}$ Democracy, $11,12-13$

Bluffton University. (2010). Bluffton magazine: An open circle education. Retrieved from http://www.bluffton.edu/ blufftonalumni/magazine/summer06/

Chickering, A. (2004). Encouraging authenticity and spirituality in higher education. Journal of College and Character, 5(1). Retrieved from http://journals.naspa.org/jcc/ vol5/iss $1 / 5 /$

Eck, D. (2003). Encountering God. Boston, MA: Beacon Press. Hurtado, S., Milem, J. F., Clayton-Pedersen, A. R., \& Allen, W. R. (1998). Enhancing campus climates for racial/ ethnic diversity: Educational policy and practice. Review of Higher Education, 21, 279-302.

Kazanjian, V. H., Jr. (2005). Towards a multi-faith community at Wellesley College. In P. Brodeur \& E. Patel (Eds.), Building the interfaith youth movement. Lanham, MD: Alta Mira Press. Retrieved from http://www. wellesley.edu/RelLife/program/dean_writings.html 
Kocet, M. M., \& Stewart, D. L. (2011). The role of student affairs in promoting religious and secular pluralism and interfaith cooperation. Journal of College \& Character, 12(1).

Kuh, G. D., Shedd, J. D., \& Whitt, E. J. (1987). Student affairs and liberal education: Unrecognized (and unappreciated) common law partners. Journal of College Student Personnel, 28, 252-260.

Lelwica, M. (2008). Religious diversity: Challenges and opportunities in the college classroom. Diversity $\mathcal{E}$ Democracy, 11, 7-9.

Macdonald, A. A., \& Sánchez-Casal, S. (2009). Introduction. In S. Sánchez-Casal \& A. A. Macdonald (Eds.), Identity in education (pp. 1-6). New York: Palgrave Macmillan.

Manning, K. (2009). Philosophical underpinnings of student affairs work on difference. About Campus, 14(2), 11-17. doi: $10.1002 / a b c .284$

Manning, K., \& Coleman-Boatwright, P. (1991). Student affairs initiatives toward a multicultural university. Journal of College Student Development, 32, 367-374.
Newman, J. H. (1996). The idea of a university (F. M. Turner, Ed.). New Haven, CT: Yale University Press.

Palmer, P. J. (1987). Community, conflict, and ways of knowing: Ways to deepen our educational agenda. Change, 19(5), 20-25.

Parks, S. D. (2000). Big questions, worthy dreams: Mentoring young adults in their search for meaning, purpose, and faith. San Francisco, CA: Jossey-Bass.

Patel, E. (2007). Religious diversity and cooperation on campus. Journal of College and Character, 9(2). Retrieved from http://www.ifyc.org/files/2007_200909170852302.11_ religious_diversity_and_cooperation_on_campus_ 200909170852302.pdf

Strange, C., \& Rogers, J. (2003). Teaching spirituality in public higher education. Religion and Education, 30(1), 24-39.

Trautvetter, L. (2007). Developing students' search for meaning and purpose. In G. Kramer (Ed.). Fostering student success in the campus community (pp. 236-261). San Francisco, CA: Jossey Bass. 